\title{
MULTILATERAL VIEW OF SHOAH EVENTS THROUGH LITERARY TEXTS
}

\author{
${ }^{a}$ MILAN MAŠÁT, ${ }^{b}$ JANA SLADOVÁ \\ University Palacký Olomouc, Faculty of Education, Žižkovo \\ náměstí 5, 77140 Olomouc, Czech Republic \\ email: ${ }^{a}$ milan.masat01@upol.cz, ${ }^{b}$ jana.sladova@upol.cz
}

Acknowledgement: This contribution was supported by IGA project IGA_PdF_2021_001_Multilateral Representation of Shoah Events in the Literature of Palacký University Olomouc.

Abstract: The paper presents the potential of literary texts with the theme of Shoah in the field of forming the desired profile of citizens of a democratic society. After the introduction, we briefly focus on the anchoring of the Shoah in Czech curricular documents focusing on the educational field of Czech Language and Literature, then we deal with the possibilities of Literary Education in the presentation of Shoah events and then the importance of multilateral perspective on the Shoah and its educational and axiological potential. We demonstrate various multilateral views on the issue of the Shoah with artistic narratives in which one line of events of the Second World War is viewed from another or from different angles.

Keywords: multilateralism, Shoah, Holocaust, literary texts, Literary Education.

\section{Introduction}

The warnings presented to us by the Shoah phenomenon are still very topical (see Abrams, 1997; Jacoby, 2016). In particular, the challenges that draw attention to various forms of ostracism, persecution, intolerance or hatred. The urgency of the issue is underlined by various researches, the center of which is the finding of perceptions of anti-Semitic sentiments in society. Some of the research surveys were conducted with respondents from among the Jews themselves, which in our opinion makes their results more urgent, relevant and more informative (for example, Antisemitic Violence in Europe, 2005-2015. Exposure and Perpetrators in France, UK, Germany, Sweden, Norway, Denmark and Russia (Due Enstad, 2017). The term Shoah in the article refers to the experience of one line of World War II events by Jews as a religious group or as an ethnic group (see Mémorial de la Shoah, 2017; Arndt, 2020).

Holý (2016, p. 573; compare Holý et al., 2011) emphasizes the need to present the events of one line of World War II through various media, which to some extent connotes multilateralism in our defined area: "The Holocaust as a historical event, let us perceive it and evaluate in any way, has become a breakthrough in the development of modern European civilization. It is the subject of an examination of history and other humanities, but also a challenge for literature and other media, especially film”.

Pohl (2020, p. 133) said "that the role of Holocaust studies for societies is very distinct has to cope with different contexts, though its main asset should remain a methodological and conceptual rigor as well as an openness to new and even more unpleasant findings. It can deliver the basis for societal discourses that transcend rituals of memorialization (...). Holocaust research can also identify and evaluate examples of help and rescue, of international intervention. Finally, the most important pursuit for our understanding of the Holocaust and the lessons to be drawn from it should be an apprehension and analysis of the destruction of democratic order or of any order based on a law-abiding state”.

Sydnor (1987 in Lindquist, 2010) summarizes the importance of the issue for today's society in the sense that the Holocaust is a standard with which people compare the importance of 20th century events, while recalling a phenomenon we must not forget because of its uniqueness. Anker (2004 in Lindquist, 2010) puts it in a similar way, arguing that in today's relativized world, in which the boundaries between good and evil are clearly outlined, one thing can be agreed upon, and that is the yardstick for absolute evil.

\section{Anchoring the term of the Shoah in Czech curricular documents}

Citizens of the Czech Republic are acquainted with various aspects related to Shoah events within the framework of institutional education in various educational fields. The most fundamental in this area is the educational field of History, which is predestined by its focus on the presentation of various events embedded in history. In this course, Czech students are introduced to the manifestations of the Second World War due to the chronological order of the curriculum in the ninth grade (see Jerrábek et al., 2017). It is not our goal to argue with the importance of some historical stages for a citizen living in the twenty-first century: here we come across a situation where students are relatively familiar with prehistoric times in the sixth grade, but the events of the second half of the twentieth century are introduced very thoroughly because there is no time left for these.

Very often, the term Shoah is synonymously confused with the term Holocaust (for a definition of the Holocaust, see Grech, 2000).. We do not consider the synonymizing of naming specific aspects of the Second World War to be an insufficient precondition for the implementation of these events into teaching or for their curricular (non)anchoring. From a terminological point of view, we see the importance of explicitly expressing the view from which the issue is viewed and, depending on the chosen focus, use common names (Mašát, 2018). Carrier et al. (2015, p. 5): comment on the indistinguishability of terminology in the field of world curricular documents: "In general, the term 'Holocaust' is used. A smaller number of curricula use the term 'Shoah' or both. In some cases, the curricula completely avoid the terms 'Holocaust' and 'Shoah'. Instead, they use alternative terms such as 'extermination' or 'Jewish genocide' and refer indirectly to the event itself (using terms such as 'concentration camp' or 'final solution'). It is worth noting that significant differences can be observed in the field of integration of the mentioned topic between schools located in Western Europe and the countries of the former Soviet Union. In schools that were under Soviet influence until the early 1990s, the issue of the Shoah, with all its connotations, is ignored or downplayed (Carrier et al., 2015). Differences can also be traced between schools within Israel, between private, state and Jewish educational institutions (see Cohen, 2016; Porat, 2004). The Israeli educational system is a model in the field of integration of the Shoah phenomenon into curricular documents. We believe that the Jewish state curriculum can be inspired by some methods or procedures of implementing a given phenomenon into a curriculum applied at various levels of institutional education.

The integration of the Shoah (Holocaust) into teaching in the Czech Republic is in the autonomy of individual schools. That autonomy results from the existence of School Educational Programs, which educational institutions create themselves, based on profiling about geographical or demographic aspects and the like. Rýdl \& Šmelová (2014, p. 15 in Mašát \& Sladová, 2019, p. 457) notes: "In the spring of 1999, the Czech government adopted a fundamental document on a new concept of the Czech education system, which was specified in the form of the so-called White book (...). A significant change is the draft three-step curriculum consisting of a national curriculum, which defines the general objectives developed by the framework educational programs for individual levels of education”. Framework Educational Programs in the Czech Republic define the boundaries of School Educational Programs, for the same level of education and broadly determine what, how and when to be taught.

The topic of the Shoah should be part of the teaching at primary schools not only regarding the aspects outlined above. As already mentioned, the term Shoah is not found in the Framework Educational Program for Basic Education, the term 
Holocaust is encountered only in the curriculum of History (see Jeřábek et al., 2017, p. 56), which, for example, given the definition of the field of Citizenship Education has a somewhat startling impression, of the given educational field with events connoting the Shoah or the Holocaust.

It is surprising that with the amount of information about the dimensions that the Shoah acquired, especially in the years 1942-1945 (see Nadler, 2011), this phenomenon was not implemented in curricular documents. We do not find the term Shoah in cross-sectional topics, which with their expected outputs (especially in the field of attitudes and values) directly encourage the integration of this topic (see Mašát, 2017; Mašát, 2018; Mašát, 2019b; compare Kreislová, 2006).

\section{The potential of literary education in the context of the presentation of Shoah events to pupils and students}

We believe that literary texts have considerable potential for presenting Shoah or Holocaust events to pupils and students at all levels of institutional education (see Jordan, 2004; Oliveira, 2017; Russel, 1997).

The results of a sound research survey, which ascertained the level of reception and interpretation of three selected texts, at the core of which is the issue of the Shoah, show that lowersecondary school pupils are largely interested in this area of literature, they are able to understand it and they are also able to interpret it - within the framework of their current factual knowledge about the period of the Second World War and depending on their cognitive development and reading experience (Mašát, 2019d; Mašát \& Šmakalová, 2020). As part of research focused on the reception of selected Shoah-texts by lower-secondary school pupils, we found, for example, that a sample from the Diary of Wilm Hosenfeld (in Szpilman, 2006), a member of the Nazi party, attracted young readers, they were able to understand it and at the same time, through an excerpt, they were acquainted with a different view of the events than what is overwhelmingly presented to them. As part of their research, Jindráček and his team (2011) concluded that activities that enrich Literary Education with a historical and cultural context are among the pupils' most popular activities (compare Hník, 2012).

A considerable number of intentional Shoah texts are currently being written (Yudin, 2019). We are of the opinion that teachers of Literary Education should choose books on the Shoah very judiciously, because not all publications, although intended for children and young people, are suitable for reception by children and teenagers living in the twenty-first century (especially the language component of narratives, possible the intentional nature of some narratives or the application of schematic techniques in certain artistic narratives). Objective reception and subsequent reflection of texts can lead to the selection of appropriate literature. This area of literature seeks to connect different narrative traditions, writing about history and the biographical area of literature with intentional literary work (Kokkola, 2003). It is important to realize that the desired educational effect can be achieved by presenting less quality literature on the Shoah than a large amount of literature that does not reach an enough artistic level. We believe that literary texts on the Shoah have the potential to attract primary school pupils, stimulate their interest, and thus influence young recipients appropriately in the field of axiological values, of course, subject to several conditions (see Esi, 2012)

The research survey, in the center of which was to find out the opinions of Czech Language and Literature teachers on the implementation of the Shoah in the teaching of Literary Education, showed that most teachers in the field of education when choosing texts (examples) from the content composition of reading-books (see Mašát, 2019b; Mašát, 2019c). As part of the analyzes of these teaching aids, which took place in 2017 and in 2020, we found that the representation of examples thematizing one line of events of the Second World War is relatively small (Mašát, 2019a; Mašát, 2017). Although there has been some progress in the positive direction over the past three years, we believe that the proportion of excerpts on the subject still does not match the message these events give to citizens living in today's global society (for example associated with a high level of xenophobic manifestations or certain forms of persecution of certain sections of the population).

\section{A multilateral view of Shoah events through selected artistic narratives}

Readers who are presented with Shoah-themed texts in order to form their desired axiological values (see Hník, 2017; Jordan, 2004; Jindráček et al., 2011; Kokkola, 2003; Oliveira, 2017) to build their moral integrity or to is to acquaint with this historical epoch through artistic narratives (compare Sladová et al., 2016) in our opinion they should be acquainted with different views on the issue. We do not want to deny the suffering of Jews, which stems from the fact that the Shoah was directed primarily against this group of people; on the other hand, we dare to say that the events taking place in today's world, at the same time, are to some extent considering the different views and arguments at the level of the actions of the various stakeholders. From the artistic literature, this work can include, for example, the work Shop on the Bark (Obchod na korze - in parentheses is the title of the publication in the language in which the book was written; if the original text was written in English, then we state only the original title), in which the Aryanization of Jewish trade is thematized, while the events connected with this process are viewed primarily from the focus of the Aryanizer. Another publication that can be included in this area is the book Puppet boy of Warsaw, which deals with the suffering of the inhabitants of the Jewish ghetto from the point of view of the interaction between a Jewish boy and a Nazi soldier. The symptomatic work falling into this area is Sunflower. A narrative of guilt and forgiveness (Sonnenblume), in which various persons comment on the question of whether a persecuted Jew has the right to forgive his German tormentor. The work Book thief is exhibited on the confrontation of experiencing one line of events of the Second World War between a Jew hiding with a German couple and their adoptive daughter. In The Storyteller, the author confronts a daughter whose mother was murdered in an extermination camp with a man who was a member of the SS during World War II.

A multilateral view of defined events can be presented through Shoah-texts from the focus of the non-Jewish population. The application of this procedure can to some extent increase the interest of recipients in texts on a given topic and possibly in the Second World War as such. The field of this literature includes, for example, the work Woman in Berlin (Frau in Berlin), which to some extent reverses the perspective of the suffering of people affected in some way by some line of World War II. In My Dad, Auschwitz Commander: The True Story of a Girl Who Grew Up as Auschwitz Commander's Daughter (Mon père le commandant), daughter of the commander of the extermination camp portrays a view of life. The publication Orphan monster spy deals with the impact of the headless decline of Nazi ideology and its effects on the next generation. The book Farewell to Sidonia (Abschied von Sidonie) presents the hitherto considerably neglected Roma Holocaust. The publications The Commander in Auschwitz (Kommandant in Auschwitz) and Death are my craft (Mort est mon métier) give readers an insight into the process of the most mass extermination of certain groups in history from the focus of its architects. Our thesis is based on the belief that everything new is interesting in a way and at least for some time we will be more interested. It is also based on the results of analyzes of reading-books (see above), which showed that the small representation of texts with the theme of Shoah is mainly represented by examples from works centered on demonstrations of the suffering of persons of Jewish nationality before World War II and World War II.

Unfortunately, texts that thematize the fate of Jews after returning from concentration or extermination camps, i.e. their post-war destinies, are largely delayed. Among the most recently published, we can mention, for example, the work Cilka's 
journey, in which the author develops the fate of one of the supporting characters of the work Tattooist of Auschwitz. After returning from the concentration camps, Cilka experiences another tyranny, this time by the communist regime. In the works Salt to the sea and Between shades of gray, the author explains the same events through different characters (different focalization). We believe that even these facts in a way fall into a multilateral view of one line of events of the World War II.

When presenting texts that show the Shoah from a different point of view than the one in the consensus, the role of the teacher in leading the lesson in which these texts are presented to the pupils is undoubtedly important. It is essential that the pedagogue masters the basic facts related to the World War II (at this point, those who have approval for the educational field of History have a somewhat simplified position), so that there are no undesirable interpretations of the presented texts artistic narratives (see Lindquist, 2008) The teacher must take into account a significant number of aspects related to the target group (see Lindquist, 2010). Fundamental discrepancies can be expressed at the level of the teacher's personal interest in a defined phenomenon. In the article titled In Teaching the Representation of the Holocaust (2004), Hirsch and Kacandes argue that the subject of the Holocaust permeates many educational disciplines (such as History, Literary Education and Psychology), with the defined phenomenon being a key part of liberal education for many teachers and students.

The multilateral view of Shoah events can also be applied at the level of comparison of various totalitarian forms of government. At this point, we will not forgive ourselves for the sip that pupils are (albeit to a small extent) acquainted in some way with literary portrayal of the Shoah phenomenon, but artistic texts in the center of which are the impacts of the communist regime on citizens or society as a whole are not in Czech reading-books for lower-secondary schools. It is not our goal to assess the extent to which the communist regime and Nazism (fascism) are similar, however, for the purposes of the impact of reading these narratives on pupils at the axiological, moral and ethical level, it does not matter to which extent we choose to adopt desirable values.

\section{Conclusion}

In our opinion, the multilateral view of the Shoah's events are far behind in Literary Education at the second stage of primary schools. The question is whether teachers are afraid of the unwanted sound of these texts, whether in terms of their distorted interpretation or the reaction of the family or school management to the fact that students are acquainted with the diary of a Nazi soldier in institutional education. However, young recipients should be acquainted with different views of the world, they should learn to look at its problems from different perspectives, they should learn to critically evaluate the information that is presented to them to a large extent in today's world, they should be able to critically and, last but not least, they should learn to argue their views. It is a different view of the issue of the Shoah (not only) through literary narratives, it is possible to teach pupils and students at various levels of institutional education these skills and abilities.

\section{Literature:}

Primary literature:

1. Frank. N.: Orphan monster spy. Praha: Práh, 2010. 398 p. ISBN: 978-80-7252-265-1.

2. Grosman, L.: Shop on the Bark (Obchod na korze). Praha: Academia, 2009. 141 p. ISBN: 978-80-200-1778-9.

3. Hackl, E.: Farewell to Sidonia (Abschied von Sidonie). Praha: Argo, 2001. 74 p. ISBN: 80-7203-337-9.

4. Höss, R.: The Commander in Auschwitz (Kommandant in Auschwitz). Praha: Academia, 2018. 349 p. ISBN: 978-80-2002813-6.

5. Cherish, B.: My Dad, Auschwitz Commander: The True Story of a Girl Who Grew Up as Auschwitz Commander's Daughter
(Mon père le commandant). Líbeznice: Víkend, 2019. 342 p. ISBN: 978-80-7433-269-2.

6. Merle, R.: Death are my craft (Mort est mon métier). Praha: Naše vojsko, 2005. 306 p. ISBN 80-206-0768-4.

7. Morris, H.: Cilka's journey. Brno: CPress, 2019. 334 p. ISBN: 978-80-264-2813-8.

8. Morris, H.: Tattooist of Auschwitz. Brno: CPress, 2019. 246 p. ISBN: 978-80-264-2496-3.

9. Piccoult, J.: The Storyteller. Praha: Ikar, 2019. 510 p. ISBN: 978-80-249-3984-1.

10. Sepetys, R.: Salt to the sea. Praha: CooBoo, 2016. 351 p. ISBN: 978-80-7544-180-5.

11. Sepetys, R.: Between shades of gray. Praha: CooBoo, 2020. 287 p. ISBN: 978-80-7661-117-7.

12. Szpilman, W.: Pianista. Praha: Academia, 2006. 255 p. ISBN: 80-200-1417-9.

13. Weaver, E.: Puppet boy of Warsaw. Praha: Mladá fronta, 2013. 308 p. ISBN: 978-80-204-3118-9.

14. Wiesenthal, S.: Sunflower. A narrative of guilt and forgiveness (Sonnenblume). Jinočany: H \& H, 2005. 126 p. ISBN: 80-7319-041-9.

15. Woman in Berlin (Frau in Berlin). Praha: Ikar, 2004. 271 p. ISBN: 80-249-0359-8.

16. Zusak, M.: Book thief. Praha: Argo, 2014. 526 p. ISBN: 97880-257-0863-7.

Secondary literature:

1. Abrams, I. M.: Elie Wiesel - Nobel Lecture. Available at: <http://www.nobelprize.org/>. 1997.

2. Anker, D.: Imaginary witness? Hollywood and the Holocaust. [Film]. New York: Anker Films, 2004.

3. Arndt, T.: Lékárny s Davidovou hvězdou v čase šoa. Osudy židovských farmaceutů v meziválečném Československu a během genocidy za druhé světové války. Praha: Academia, 2020. 464 p. ISBN: 978-80-200-3049-8.

4. Carrier, P. et al.: The International status of education about the Holocaust: a global mapping of textbooks and curricula. Paris: UNESCO, 2015. 235 p. ISBN: 978-92-3-100033-1.

5. Cohen, E., H.: Teacher autonomy within a flexible national curriculum: development of Shoah (holocaust) education in Israeli state school. Curriculum Studies, Vol. 48, No. 2. 2016. p. 167-191. ISSN: 1366-5839. Available at: <https://doi.org/10 .1080/00220272.2015.1033464>.

6. Due Enstad, J.: Antisemitic Violence in Europe, 2005-2015. Exposure and Perpetrators in France, UK, Germany, Sweden, Denmark and Russia. Oslo: University of Oslo, 2017. 31 p.

7. Esi, M., C.: Axiological Dimensions in the Educational Process. LOGOS, UNIVERSALITY, MENTALITY, EDUCATION, NOVELTY, Vol. 1, No 1. 2012. p. 73-83. ISSN: 2284-5968. Available at: <https://www.ceeol.com/search/articledetail?id=143899>

8. Grech, L.: Teaching about the Holocaust. Strasbourg: Council for Cultural Co-operation, 2000. 37 p.

9. Hirsch, M., Kacandes, I.: Teaching the Representation of the Holocaust. New York: Modern Language Association of America, 2004. 512 p. ISBN: 9780873523486.

10. Hník, O..: Didaktika literatury: výzvy oboru. Od textů umělecké povahy $\mathrm{k}$ didaktice estetickvýchovného oboru. Praha: Karolinum, 2014. 179 p. ISBN: 978-80-246-2626-0.

11. Hník, O.: Literární výchova a rozvoj čtenářství. In Wildová, R. et al.: Čtenářská gramotnost a podpora jejího rozvoje ve škole Praha: Univerzita Karlova, 2012. p. 137-147. ISBN: 978-807290-579-9.

12. Holý, J.: Šoa ve fikční próze do konce šedesátých let. In Holý, J.: Cizí i blízcí. Židé, literatura, kultura v českých zemích ve 20. století Praha: Akropolis, 2016. p. 573-600. ISBN: 97880-7470-125-2.

13. Holý, J. et al.: Šoa v české literatuře a v kulturní paměti. Praha: Akropolis, 2011. 309 p. ISBN: 978-80-87481-14-1.

14. Jacoby, J.: Forgeting the Holocaust. Available at: $<$ https://www.aish.com/jw/s/Forgetting-the-Holocaust.html>. 2016.

15. Jeřábek, J. et al.: Rámcový vzdělávací program pro základni vzdělávání (Framework educational program for basic education). Praha: NÚV, 2017. 166 p. 
16. Jindráček, V. et al.: Dětská pojetí uměleckého textu jako východiska školní interpretace. Ústí nad Labem: Univerzita Jana Evangelisty Purkyně, 2011. 282 p. ISBN: 978-80-7414-429-5.

17. Jordan, S., D.: Educating Without Overwhelming: Authorial Strategies in Children's Holocaust Literature. Children's Literature in Education, Vol 35, No 3. 2004. p. 199-217. ISSN: 0045-6713 Available at: <https://doi.org/10.1023/B:CLID .0000041779.63791.ae>.

18. Kokkola, L.: Representing the Holocaust in Children's Literature. New York: Routledge, 2003. 220 p. ISBN: 9780415803656.

19. Kreislová, A.: K možnostem využití uměleckých textů v průřezových tématech. In Fridrich, R., Fibiger, M.: Výuka národní literatury $\mathrm{v}$ mezipředmětových. Ústí nad Labem: Univerzita Jana Evangelisty Purkyně, 2006. p. 13-21. ISBN: 807044-767-2.

20. Mašát, M.: Implementation of the Shoah theme into the teaching of literature education in the context of reading-books.

In Králík, J.: Recenzovaný sborník příspěvků vědecké interdisciplinární mezinárodní vědecké konference doktorandů a odborných asistenti̊ QUAERE Hradec Králové: Magnanimitas, 2019a. p. 508-517. ISBN: 978-80-87952-30-6.

21. Mašát, M.: K implementaci tematiky šoa do výuky literární výchovy z pohledu učitelu. Paidagogos, Vol. 1, No. 3. 2019b. p. 35-61. ISSN: 1213-3809. Available at: <http://www.paidago gos.net/issues/2019/1/article.php?id=3>.

22. Mašát, M.: K uplatnění tematiky šoa v literárních čítankách pro druhý stupeň základních škol. Jazyk - literatura komunikace, Vol. 2017, No. 2. 2017. p. 68-78. ISSN: 1805689X. Available at: <http://jlk.upol.cz/index.php/cislo-2-2017>. 23. Mašát, M.: K vybraným faktorům implementace tematiky šoa do výuky literární výchovy. In Duchovičová Hošová, D., Koleňáková, R., Š.: Inovatívne trendy v odborových didaktikách. Prepojenie teórie a praxe výučbových stratégií kritického a tvorivého myslenia. Nitra: Pedagogická fakulta UKF v Nitre, 2019c. p. 451-456. ISBN 978-80-558-1408-7. Available at: <https://www.pf.ukf.sk/images/docs/projekty/2017/pC-Cp/ko nferencie/2019/APVV\%20Zborn\%C3\%ADk\%202019.pdf>. 24. Mašát, M.: Komparace recepce vybraných textů s tematikou šoa žáky šestých a devátých ročnikủ základních škol. In Králík, J.: Recenzovaný sborník příspěvků mezinárodní vědecké konference MMK 2019: Mezinárodní Masarykova konference pro doktorandy a mladé vědecké pracovníky. Hradec Králové: Magnanimitas, 2019d. p. 490-499. ISBN: 978-80-87952-30-6.

25. Mašát, M.: Zastoupení termínů šoa a holokaust ve vybraných kurikulárních dokumentech. In Králík, J.: Recenzovaný sborník příspěvků vědecké interdisciplinární mezinárodní vědecké konference doktorandů a odborných asistentů QUAERE. Hradec Králové: Magnanimitas, 2018. p. 802-809. ISBN: 978-8087952-26-9.

26. Mašát, M., Sladová, J.: Representations of Shoah and Holocaust Terms in Selected Curriculum Documents: A Teacher's Perspective. Universal Journal of Educational Research, Vol. 7, No. 2. 2019. p. 457-462. ISSN: 2332-3213. Available at: <https://doi.org/10.13189/ujer.2019.070218>. 27. Mašát, M., Šmakalová, K. Reception of Selected Texts with the Theme of Shoah by Students of the Lower Secondary School. In Petkova, T., V., Chukov, V., S.: 5rd International eConference on Studies in Humanities and Social Sciences: Conference Proceedings Belgrade: Center for Open Access in Science, 2020. p. 69-82. ISBN: 978-86-81294-05-5. Available at: <https://doi.org/10.32591/coas.e-conf.05.06069m>.

28. Mémorial de la Shoah: What is the Shoah? Available at: <http://www.memorialdelashoah.org/>. 2017.

29. Lindquist, D., H.: Complicating Issues in Holocaust Education. Journal of Social Studies Research, Vol. 34, No. 1. 2010. p. 77-93. ISSN: 0885-985X. Available at: <https://eric .ed.gov/?id=EJ887319>.

30. Lindquist, D., H.: Developing Holocaust Curricula: The Content Decision-Making Process. A Journal of Educational Strategies. Issues and Ideas, Vol. 82, No. 1. 2008. p. 27-34. ISSN: 1939-912X. Available at: <https://doi.org/1 0.3200/TCHS.82.1.27-34>.

31. Oliveira, W., M.: In Search of Over There: Education, Space, and Language. Educação \& Realidade, Vol. 42, No. 3.
2017. p. 1161-1182. ISSN: 2175-6236. Available at: <https://do i.org/10.1590/2175-623660859>.

32. Pohl, D.: Holocaust Studies in Our Societies. S: I. M. O. N. SHOAH: INTERVENTION. METHODS. DOCUMENTATION, Vol. 7, No. 1. 2020. p. 133-141. ISSN: 2408-9192. Available at: <https://doi.org/10.23777/SN.0120 /SWL_DPOH01>.

33. Porat, D., A.: From the Scandal to the Holocaust in Israeli Education. Journal of Contemporary History, Vol. 39, No. 4. 2004. p. 619-636. ISSN: 1461-7250. Available at: <https://doi.o rg/10.1177/0022009404046757>.

34. Russell, D., L.: Reading the Shards and Fragments: Holocaust Literature for Young Readers. The Lion and the Unicorn, Vol. 21, No. 2. 1997. p. 267-280. ISSN: 1080-6563. Available at: <https://doi.org/10.1353/uni.1997.0043>.

35. Rýdl, K., Šmelová, E.: Reforma s atributem nekonsekventnosti. In Kasper, T., Dymokurský, O.: Reforma vzdělávání $\mathrm{v}$ současné kurikulární diskusi. Brno: Česká pedagogická společnost, 2014. p. 9-22. ISBN: 978-80-905245$1-4$.

36. Sladová, J. et al.: Umélecká literatura v procesu osobnostní a sociální výchovy. Olomouc: Univerzita Palackého v Olomouci, 2016. 134 p. ISBN: 978-80-244-5101-5.

37. Sydnor, Jr., C. W.: "How can you bear to teach the Holocaust?" "How can we not?" Chronicle of Higher Education, Vol. 34. No. 3: A52. 1987.

38. Yudin, L., Y.: Introduction. In Abramovich, D.: Fragments of Hell. Israeli Holocaust Literature. Brighton: Academic Studies Press, 2019. p. 1-19. ISBN: 9781644692622.

\section{Primary Paper Section: A}

Secondary Paper Section: AM 